\title{
KLLN Gene
}

National Cancer Institute

\section{Source}

National Cancer Institute. KLLN Gene. NCI Thesaurus. Code C95286.

This gene is involved in both DNA binding and apoptosis regulation. 